\title{
PENATAAN PARKIR DI RUAS JALAN GAJAH MADA DAN RUAS JALAN JENDRAL SUDIRMAN DI KABUPATEN PONOROGO
}

\author{
Ridwan Tuasikal $^{1}$, Budiharso Hidayat ${ }^{2 *}$, Djajadi $^{3}$ \\ 1), 2), 3)PTDI-STTD \\ *Email: budiharso.hidayat@ptdisttd.ac.id
}

\begin{abstract}
$\mathrm{f}$

In this study, the authors take a case study on on-street parking on Road Gajah Mada and Road Jendral Sudirman. Both of these roads is one of the centers of economic activity and the biggest attraction. However, due to lack of vehicle parking spaces are provided for visitors of the region, causing many vehicles parked on the road. On-street parking that is applied to each segment is parked at an angle of $45^{\circ}$ with the markers. However, there are several parked vehicles are still not organized in a parked vehicle so it sometimes takes a larger parking space. So indirectly parkr conditions on this street leads to reduced effective width of roads in the road and affect the rated capacity. The results of the analysis show the provision of on-street parking will be parking spaces still exceeds demand existing parking. However, because there is no parking arrangement is good, then the parking of vehicles such irregular roads lead to reduced performance, for example, the existing condition in Road Gajah Mada with road capacity in 1187 (smp/hour), V / C ratio of 0.55, the speed 28.23 trip $(\mathrm{km} / \mathrm{h})$ and a density of $42.04(\mathrm{smp} / \mathrm{km})$. The proposed recommendations in the form of performance enhancing road by imposing side parking and 90 parking angle determination for vehicles of motorcycles and 0 for a vehicle type of private cars and pick ups. Besides doing the calculations to find out how the angle of the proposal are applied can be applied effectively.
\end{abstract}

Keywords: parking, road performance, $v / c$ ratio, the speed of travel, the density.

\begin{abstract}
ABSTRAK
Pada penelitian ini penulis mengambil studi kasus mengenai parkir on street di ruas Jalan Gajah Mada dan Jalan Jendral Sudirman. Kedua ruas jalan tersebut merupakan salah satu pusat kegiatan perekonomian dan tarikan terbesar. Namun akibat minimnya ruang parkir kendaraan yang disediakan untuk pengunjung kawasan tersebut, menyebabkan banyak kendaraan yang parkir di badan jalan. Parkir on street yang diterapkan pada tiap-tiap ruas adalah parkir dengan sudut $45^{\circ}$ dengan marka. Namun terdapat beberapa kendaraan parkir yang masih belum teratur dalam memarkirkan kendaraannya sehingga terkadang memakan ruang parkir yang lebih besar. Maka secara tidak langsung kondisi parkr on street ini menyebabkan berkurangnya lebar efektif ruas jalan di jalan tersebut dan mempengaruhi nilai kapasitasnya. Hasil analisis parkir on street menunjukan penyediaan akan ruang parkir masih melebihi permintaan parkir yang ada. Namun karena tidak ada penataan parkir yang baik, maka kendaraan yang parkir tidak teratur tersebut mengakibatkan berkurangnya kinerja ruas jalan, contohnya pada kondisi eksisting di ruas Jalan Gajah Mada dengan kapasitas jalan 1187 (smp/jam), V/C Ratio 0,55, kecepatan perjalanan 28,23 (km/jam) dan kepadatan 42,04 (smp/km). Rekomendasi yang diusulkan berupa peningkatkan kinerja ruas jalan dengan memberlakukan parkir sisi dan penentuan sudut parkir $90^{\circ}$ untuk kendaraan jenis sepeda motor dan $0^{\circ}$ untuk kendaraan jenis mobil pribadi dan pick up. Selain itu melakukan perhitungan untuk mengetahui berapa tahun sudut usulan yang diterapkan dapat diberlakukan dengan efektif.

Kata Kunci: parkir, kinerja ruas jalan, v/c ratio, kecepatan perjalanan, kepadatan.
\end{abstract}

\section{PENDAHULUAN}

Perkembangan jumlah penggunaan kendaraan bermotor saat ini tidak seimbang dengan perkembangan jaringan jalan yang ada. Jumlah penggunaan kendaraan bermotor mengalami pertumbuhan yang lebih cepat dibandingkan dengan jaringan jalan yang disediakan sehingga menimbulkan salah satu masalah transportasi yaitu kemacetan. Untuk 
mengembangkan jaringan jalan sendiri tentunya memiliki berbagai kendala baik dari segi biaya maupun lahan.

Jumlah penggunaan kendaraan bermotor berkembang akibat aktivitas masyarakat yang terus meningkat. Maka dari itu dengan tersedianya sarana transportasi, tentunya sangat membantu pergerakan masyarakat dalam melakukan aktivitasnya. Namun seiring dengan bertambahnya jumlah penduduk menyebabkan jumlah penggunaan kendaaran juga meningkat, khususnya untuk penggunaan kendaraan pribadi.

Setiap penggunaan kendaraan pasti membutuhkan tempat untuk memberhentikan kendaraannya untuk suatu kegiatan atau keperluan tertentu. Maka dari itu harus disediakan fasilitas yang dapat menunjang kebutuhan tersebut yaitu berupa fasilitas parkir. Terdapat dua jenis fasilitas parkir yaitu parkir di badan jalan (on street parking) dan parkir di luar badan jalan (off street parking). Pemilik kendaraan tentunya menginginkan kendaraannya parkir di tempat yang aman, mudah dicapai, dekat dengan tujuan, dan jika dikenai biaya masih bisa dijangkau.

Aktivitas masyarakat pada umumnya menuju pada tempat-tempat yang mempunyai tarikan perjalanan yang tinggi, misalnya tempat kerja, sekolah, pertokoan, pasar, dan lainnya. Dengan melihat hal tersebut perlu dilakukan adanya suatu pengaturan mengenai penataan parkir ditempat-tempat tersebut dengan tujuan agar masyarakat yang memberhentikan atau memarkirkan kendaraannya dengan maksud tertentu di termpat-tempat tersebut tidak mengganggu kelancaran lalu lintas yang ada disekitar tempat tersebut.

Di Kabupaten Ponorogo retribusi parkir diatur dalam Peraturan Daerah Kabupaten Ponorogo Nomor 14 Tahun 2011 Tentang Retribusi Jasa Umum yang di dalamnya terdapat aturan tentang tarif retribusi pelayanan parkir di tepi jalan umum. Penyediaan fasilitas parkir merupakan salah satu jalan keluar yang terbaik sebagai prasarana untuk menghindari kemungkinan-kemungkinan terburuk yang akan di dapat nantinya dari penggunaan kendaraan pribadi yang terus meningkat. Dan oleh karena itulah perlu dilakukan kajian mengenai penataan kendaraan yang parkir di tempat yang mempunyai tarikan perjalanan yang tinggi di Wilayah Kabupaten Ponorogo khususnya di ruas Jalan Gajah Mada dan ruas Jalan Jendral Sudirman.

Pada kedua ruas jalan tersebut tingkat akumulasi parkir dalam satu hari bisa mencapai angka 2800 kendaraan karena terdapat salah satu pusat kegiatan perekonomian dengan transaksi jual beli setiap harinya dan menjadi pusat tarikan terbesar di Wilayah Kabupaten Ponorogo. Komposisi tempat jual beli yang tersedia berupa minimarket, toko, rumah toko, rumah makan, dan pedangang kaki lima. Pertokoan pada ruas Jalan Gajah Mada dan ruas Jalan Jendral Sudirman sebagian besar tidak memiliki ruang parkir tersendiri sehingga untuk parkir off street yang sangat minim untuk menampung kendaraan menyebabkan kapasitas yang dapat ditampung tidak sesuai dengan permintaan yang ada dan membuat banyak kendaraan yang memilih parkir di badan jalan (on street).

Dengan adanya suatu penataan parkir yang efektif pada jalan tersebut diharapkan nantinya dapat mempengaruhi kinerja ruas jalan seperti tingkat pelayanan jalan, kecepatan perjalanan dan kepadatan kendaraan yang berada di jalan. Sehingga dengan begitu tidak akan lagi mengganggu kinerja ruas jalan disekitar jalan tersebut. Dari uraian permasalah tersebut maka dilakukan suatu penelitian mengenai penataan parkir di ruas jalan gajah mada dan ruas Jalan Jenderanl Sudirman di Kabupaten Ponorogo. 


\section{KAJIAN LITERATUR}

\section{Aspek Teori}

Parkir adalah keadaan Kendaraan berhenti atau tidak bergerak untuk beberapa saat dan ditinggalkan pengemudinya.(UU No.22 Tahun 2009 Tentang Lalu Lintas dan Angkutan Jalan). Penataan merupakan suatu proses perencanaan, pemanfaatan ruang dan pengendalian pemanfaatan. Akumulasi Parkir adalah jumlah kendaraan yang diparkir di suatu tempat pada waktu tertentu, dan dapat dibagi sesuai dengan kategori jenis maksud perjalanan.

Durasi Parkir adalah rentang waktu sebuah kendaraan parkir di suatu tempat (dalam satuan menit atau jam). Pergantian parkir (turn over parking) adalah tingkat penggunaan ruang parkir dan diperoleh dengan membagi volume parkir dengan jumlah ruang-ruang parkir untuk satu periode tertentu. Indeks Parkir adalah ukuran untuk menyatakan penggunaan panjang jalan dan dinyatakan dalam presentase ruang yang ditempati oleh kendaraan parkir.

Satuan Ruang Parkir (SRP) adalah ukuran luas efektif untuk meletakkan kendaraan (mobil penumpang, bus/truk atau sepeda motor), termasuk ruang bebas dan lebar bukaan pintu. Jarak Berjalan adalah jarak berjalan kaki dari ruang parkir menuju ke tempat tujuan perjalanan. Kapasitas jalan jumlah lalu lintas maksimum yang dapat didukung oleh ruas jalan pada keadaan tertentu (geometrik, komposisi, dan distribusi lalu lintas juga faktor lingkungan) sesuai dengan standar Manual Kapasitas Jalan Indonesia.

Kawasan Pusat Kegiatan (Central Business District) adalah kawasan pusat kegiatan masyarakat yang dapat berupa perkantoran, pertokoan, industri, atau pasar yang menimbulkan tarikan perjalanan. Kecepatan Perjalanan adalah perbandingan antara jarak perjalanan dengan waktu perjalanan. Kebutuhan Parkir adalah jumlah ruang parkir yang dibutuhkan yang besarnya dipengaruhi oleh berbagai faktor seperti tingkat pemilikan kendaraan pribadi, tingkat kesulitan menuju daerah yang bersangkutan, ketersediaan angkutan umum, tarif parkir.

Kinerja ruas jalan menurut Manual Kapasitas Jalan Indonesia (2007), menyatakan bahwa ukuran kinerja ruas jalan dapat ditentukan dari: Arus dan komposisi lalu lintas, kecepatan arus bebas, kapasitas, derajat kejenuhan, kecepatan, dan waktu tempuh. Panjang Antrian didefinisikan sebagai banyaknya kendaraan yang antri pada mulut persimpangan pada saat lampu lalu lintas dalam keadaan merah. Semakin panjang antrian yang terjadi, dapat dikatajan kinerja persimpangan makin buruk.

Parkir di badan jalan atau "on street parking" adalah fasilitas parkir yang menggunakan tepi jalan. Parkir di luar badan jalan atau "off street parking" adalah fasilitas parkir kendaraan di luar tepi jalan umum yang dibuat khusus atau penunjang yang dapat berupa parkir dan/atau gedung parkir. Parkir Menyudut adalah kendaraan yang sedang berhenti di badan jalan yang membentuk sudut terhadap arus lalu lintas.

Parkir Paralel adalah kendaraan yang sedang berhenti di badan jalan yang sejajar dengan arah arus lalu lintas. Peluang Antrian adalah peluang antrian dengan lebih dari dua kendaraan didaerah pendekat yang mana saja, pada simpang tak bersinyal. Ruas jalan atau link adalah ruas jalan yang dibatasi oleh dua node atau simpang. Volume lalu lintas adalah jumlah kendaraan yang melewati suatu titik pada jalan persatuan waktu, dinyatakan dalam kendaraan perjam atau satuan mobil penumpang (smp/jam). Volume Parkir adalah jumlah 
keseluruhan kendaraan yang menggunakan fasilitas parkir, biasanya dihitung dalam kendaraan yang diparkir dalam satu hari.

\section{Aspek Teknis}

Dalam penelitian serta penganalisaan data pada Kertas Kerja Wajib ini digunakan rumus rumus dasar yang menjadi landasan dalam analisis data dan usulan berupa:

a) Kapasitas Statis

Penyediaan kapasitas parkir yang akan disediakan atau yang akan ditawarkan untuk memenuhi permintaan parkir.

$$
K S=\frac{L}{X}
$$

b) Kapasitas Dinamis

Kapasitas parkir yang tersedia (kosong selama waktu survei yang diakibatkan oleh kendaraan).

$$
K D=\frac{K s \times P}{D}
$$

c) Durasi Parkir

Tergantung pada rata - rata lamanya kendaraan yang parkir.

$$
D=\frac{\text { Kendaraan Parkir } \times \text { Lamanya parkir }}{\text { Jumlah Kendaraan }}
$$

d) Penggunaan Parkir (Indeks Parkir)

Penggunaan parkir merupakan persentase penggunaan parkir pada setiap waktu atau perbandingan antara akumulasi dengan kapasitas.

$$
I P=\frac{\text { Akumulasi }(\text { kend }) \times 100 \%}{K s}
$$

e) Tingkat Pergantian Parkir (Turn Over)

Penggunaan ruang parkir yang merupakan perbandingan volume parkir untuk suatu periode waktu tertentu dengan jumlah ruang parkir/kapasitas parkir.

$$
\text { Turn over }=\frac{\text { jumlahkendaraan }}{K S}
$$

f) Volume Parkir

Merupakan jumlah keseluruhan kendaraan yang menggunakan fasilitas parkir pada suatu ruang parkir per satuan waktu, diukur selama 1 (satu) hari atau selama waktu survei dengan interval waktu 15 (lima belas) menit selama 12 jam. 
g) Akumulasi Parkir

Merupakan jumlah total kendaraan yang parkir pada suatu kawasan dalam waktu tertentu. Waktu puncak parkir dan jumlah kendaraan yang parkir pada waktu puncak akan diperoleh dari perhitungan akumulasi parkir.

h) Kapasitas Jalan

Berdasarkan Manual Kapasitas Jalan Indonesia (1997), perhitungan kapasitas jalan perkotaan menggunakan rumus berikut.

$$
C=C o \times F w \times F s p \times F s f x F c s
$$

i) Kecepatan Perjalanan

Perubahan perbandingan volume dengan kapasitas jalan (V/C ratio) akan mempengaruhi perubahan pada kecepatan di ruas jalan.

$$
V=F V \times 0.5\left(1+(1-D S)^{0.5}\right.
$$

j) Kecepatan Arus Bebas

Kecepatan digunakan sebagai salah satu ukuran kinerja ruas jalan.

$$
F V=(F V o+F V w) \times F F V s f \times F F V c s
$$

k) Kepadatan (smp/kilometer)

Kepadatan digunakan sebagai salah satu ukuran kinerja ruas jalan.

$$
\text { Kepadatan }=\frac{\text { volumelalulintas }}{\text { kecepatan }}
$$

1) Forecasting

Forecasting (peramalan) tahun rencana menggunakan rumus Compounding factor sebagai berikut.

$$
\mathrm{Pt}=\mathrm{Po} x(1+\mathrm{i})^{\mathrm{n}}
$$

\section{METODE}

Metode dalam penelitian ini adalah metode kualitatif dengan pendekatan studi deskriptif analitis. Menurut Sugiyono (2012:9) metode kualitatif adalah metode penelitian yang digunakan pada kondisi objek yang alamiah, di mana peneliti adalah sebagai instrumen kunci, dalam metode ini peneliti melakukan pengumpulan data secara langsung pada lapangan (observasi). Kemudian data yang diteliti akan dikemukakan dalam bentuk tabel, grafik, garis, diagram lingkaran maupun gambaran secara visual. 


\section{PEMBAHASAN}

\section{Kondisi Parkir Eksisting}

a) Akumulasi Parkir

Dari hasil akumulasi yang dilakukan tiap 15 menit selama 12 jam untuk Jalan Gajah Mada, Jendral Sudirman I, dan Jendral Sudirman II (waktu penelitian pada pukul 08.00-20.00 WIB), dapat diketahui jumlah kendaraan yang parkir dan waktu puncak.

Tabel 1. Akumulasi Parkir

\begin{tabular}{|c|c|c|c|c|c|}
\hline Lokasi Parkir & Jam Puncak & $\begin{array}{c}\text { Sepeda } \\
\text { Motor } \\
\text { (Kend) }\end{array}$ & $\begin{array}{c}\text { Mobil } \\
\text { Pribadi } \\
\text { (Kend) }\end{array}$ & $\begin{array}{c}\text { Pick Up } \\
\text { (Kend) }\end{array}$ & $\begin{array}{c}\text { Akumulasi } \\
\text { Parkir (Kend) }\end{array}$ \\
\hline Jalan Gajah Mada & $09.30-09.45$ & 42 & 7 & 16 & 65 \\
\hline Jalan Jendral Sudirman I & $12.15-12.30$ & 12 & 9 & 20 & 41 \\
\hline Jalan Jendral Sudirman II & $17.00-17.15$ & 87 & 10 & 18 & 115 \\
\hline
\end{tabular}

b) Kapasitas Statis

Besarnya nilai kapasitas statis dipengaruhi oleh panjang dan sudut parkir. Berikut adalah contoh perhitungan kapasitas statis pada parkir on street Jalan Gajah Mada yaitu dengan sudut $45^{0}$ dengan jenis kendaraan mobil pribadi dan pick up yaitu sebagai berikut:

Tabel 2. Kapasitas Statis Mobil Pribadi dan Pick Up

\begin{tabular}{|c|c|c|c|c|}
\hline Nama Jalan & $\begin{array}{c}\text { Panjang } \\
\text { Jalan (m) }\end{array}$ & Sudut (x $\left.{ }^{0}\right)$ & $\begin{array}{c}\text { Lebar kaki ruang } \\
\text { parkir (m) }\end{array}$ & $\begin{array}{c}\text { Kapasitas } \\
\text { statis (SRP) }\end{array}$ \\
\hline Gajah Mada & 155 & 45 & 3.7 & 42 \\
\hline Jendral Sudirman I & 138 & 45 & 3.7 & 47 \\
\hline Jendral Sudirman II & 173 & 45 & 3.7 & \\
\hline
\end{tabular}

Kapasitas statis kendaraan sepeda motor pada lokasi parkir di ruas jalan yang dikaji dapat dilihat lebih rinci dalam Tabel V.3 sebagai berikut:

Tabel 3. Kapasitas Statis Sepeda Motor

\begin{tabular}{|c|c|c|c|}
\hline Nama Jalan & $\begin{array}{c}\text { Panjang } \\
\text { Jalan (m) }\end{array}$ & $\begin{array}{c}\text { Lebar kaki ruang } \\
\text { parkir (m) }\end{array}$ & $\begin{array}{c}\text { Kapasitas } \\
\text { statis (SRP) }\end{array}$ \\
\hline Gajah Mada & 50 & 0.75 & 67 \\
\hline Jendral Sudirman I & 40 & 0.75 & 87 \\
\hline Jendral Sudirman II & 65 & 0.75 & \multicolumn{2}{c|}{} \\
\hline
\end{tabular}

c) Durasi Parkir

Durasi rata-rata kendaraan jenis sepeda motor tertinggi berada pada ruas Jalan Jendral Sudirman II. Sedangkan untuk durasi rata-rata jenis kendaraan mobil pribadi dan pick up tertinggi berada pada ruas Jalan Gajah Mada. Rata-rata durasi parkir pada ruas jalan tersebut dapat dilihat dalam Tabel 4 dibawah ini. 
Tabel 4. Durasi Parkir

\begin{tabular}{|c|c|c|c|}
\hline \multirow{2}{*}{ Lokasi Parkir } & \multicolumn{3}{|c|}{ Rata-rata Durasi (Menit) } \\
\cline { 2 - 4 } & $\begin{array}{c}\text { Sepeda } \\
\text { Motor }\end{array}$ & Mobil Pribadi & Pick Up \\
\hline Gajah Mada & 45.90 & 140.91 & 180.00 \\
\hline Jendral Sudirman I & 64.00 & 76.74 & 91.00 \\
\hline Jendral Sudirman II & 93.65 & 81.78 & 98.00 \\
\hline
\end{tabular}

d) Kapasitas Dinamis

Kapasitas dinamis tergantung pada besarnya rata-rata durasi atau lamanya kendaraan parkir. Jadi besarnya kapasitas dinamis atau suatu ruang parkir di Jalan Gajah Mada dapat digunakan sebanyak 211 ruang untuk mobil pribadi dalam sehari. Kapasitas dinamis jalan di wilayah studi dapat dilihat dalam Tabel 5 dan Tabel V.6.

Tabel 5. Kapasitas Dinamis Mobil Penumpang dan Pick Up

\begin{tabular}{|c|c|c|c|c|c|c|c|c|}
\hline \multirow[b]{2}{*}{ No } & \multirow[b]{2}{*}{ Nama Jalan } & \multirow[b]{2}{*}{$\begin{array}{l}\text { Sudut } \\
\text { Parkir }\end{array}$} & \multirow[b]{2}{*}{$\begin{array}{c}\text { Kapasitas } \\
\text { Statis }\end{array}$} & \multicolumn{2}{|c|}{ Durasi Parkir (jam) } & \multirow[b]{2}{*}{$\mathrm{P}$} & \multicolumn{2}{|c|}{ Hasil Kapasitas Dinamis } \\
\hline & & & & $\begin{array}{l}\text { Mobil } \\
\text { Pribadi }\end{array}$ & $\begin{array}{l}\text { Pick } \\
\text { Up }\end{array}$ & & $\begin{array}{l}\text { Mobil } \\
\text { Pribadi }\end{array}$ & Pick Up \\
\hline \multirow{5}{*}{1} & \multirow{5}{*}{ Gajah Mada } & 0 & 26 & \multirow{5}{*}{2.38} & \multirow{5}{*}{0.81} & \multirow{5}{*}{12} & 130 & 383 \\
\hline & & 30 & 31 & & & & 156 & 459 \\
\hline & & 45 & 42 & & & & 211 & 621 \\
\hline & & 60 & 52 & & & & 261 & 765 \\
\hline & & 90 & 62 & & & & 313 & 919 \\
\hline \multirow{5}{*}{2} & \multirow{5}{*}{$\begin{array}{c}\text { Jendral } \\
\text { Sudirman I }\end{array}$} & 0 & 23 & \multirow{5}{*}{1.26} & \multirow{5}{*}{1.27} & \multirow{5}{*}{12} & 219 & 217 \\
\hline & & 30 & 28 & & & & 263 & 261 \\
\hline & & 45 & 37 & & & & 355 & 352 \\
\hline & & 60 & 46 & & & & 438 & 435 \\
\hline & & 90 & 55 & & & & 526 & 522 \\
\hline \multirow{5}{*}{3} & \multirow{5}{*}{$\begin{array}{c}\text { Jendral } \\
\text { Sudirman II }\end{array}$} & 0 & 29 & \multirow{5}{*}{1.37} & \multirow{5}{*}{1.61} & \multirow{5}{*}{12} & 253 & 215 \\
\hline & & 30 & 35 & & & & 303 & 258 \\
\hline & & 45 & 47 & & & & 410 & 348 \\
\hline & & 60 & 58 & & & & 505 & 430 \\
\hline & & 90 & 69 & & & & 606 & 516 \\
\hline
\end{tabular}

Tabel 6. Kapasitas Dinamis Sepeda Motor

\begin{tabular}{|c|c|c|c|c|}
\hline Nama Ruas & Interval Survey (P) & KS (SRP) & D (Jam) & $\begin{array}{c}\text { KD } \\
\text { (SRP) }\end{array}$ \\
\hline Gajah Mada & 12 & 67 & 0.79 & 1013 \\
\hline Jendral Sudirman I & 12 & 47 & 1.05 & 537 \\
\hline Jendral Sudirman II & 12 & 73 & 1.43 & 613 \\
\hline
\end{tabular}

e) Volume Parkir

Berikut merupakan volume kendaraan parkir waktu penelitian selama 12 jam dapat dilihat dalam Tabel V.7 dibawah ini. 
Tabel 7. Volume Kendaraan Parkir

\begin{tabular}{|c|c|c|c|}
\hline \multirow{2}{*}{ Lokasi Parkir } & \multicolumn{3}{|c|}{ Volume Kendaraan Parkir (Kend) } \\
\cline { 2 - 4 } & Sepeda Motor & Mobil Pribadi & Pick Up \\
\hline Gajah Mada & 359 & 124 & 323 \\
\hline Jendral Sudirman I & 79 & 124 & 147 \\
\hline Jendral Sudirman II & 688 & 208 & 64 \\
\hline
\end{tabular}

f) Penggunaan Parkir

Tingkat penggunaan ruang parkir pada setiap waktu atau penggunaan ruang parkir dilihat dari perbandingan antara akumulasi dan kapasitas pada ruas Jalan Gajah Mada untuk mobil pribadi adalah $16,7 \%$ yang artinya permintaan parkir belum melebihi kapasitas yang disediakan. Berikut ini adalah indeks parkir pada setiap ruas wilayah penelitian dapat dilihat dalam Tabel 8 dan Tabel 9 berikut ini.

Tabel 8. Indeks Parkir Mobil Pribadi dan Pick Up

\begin{tabular}{|c|c|c|c|c|c|}
\hline \multirow{2}{*}{ Lokasi Parkir } & \multicolumn{4}{|c|}{$\begin{array}{c}\text { Akumulasi Kendaraan Parkir } \\
\text { (kend) } \\
\text { KapasitasStati } \\
\text { s (Ks) }\end{array}$} & \multicolumn{3}{|c|}{ Indeks parkir Per Jam ( \% ) } \\
\cline { 3 - 6 } & & $\begin{array}{c}\text { Mobil } \\
\text { Pribadi }\end{array}$ & Pick Up & $\begin{array}{c}\text { Mobil } \\
\text { Pribadi }\end{array}$ & Pick Up \\
\hline Gajah Mada & 42 & 7 & 25 & 16.7 & 357.1 \\
\hline $\begin{array}{c}\text { Jendral Sudirman } \\
1\end{array}$ & 37 & 9 & 23 & 24.3 & 255.6 \\
\hline $\begin{array}{c}\text { Jendral Sudirman } \\
2\end{array}$ & 47 & 35 & 16 & 74.5 & 45.7 \\
\hline
\end{tabular}

Tabel 9. Indeks Parkir Sepeda Motor

\begin{tabular}{|c|c|c|c|}
\hline \multirow{2}{*}{ Lokasi Parkir } & \multirow{2}{*}{$\begin{array}{c}\text { Kapasitas Statis ( } \\
\text { Ks ) }\end{array}$} & $\begin{array}{c}\text { Akumulasi } \\
\text { Kendaraan Parkir } \\
\text { (kend) }\end{array}$ & $\begin{array}{c}\text { Indeks parkir Per } \\
\operatorname{Jam}(\%)\end{array}$ \\
\hline & & \multicolumn{2}{|c|}{ Sepeda Motor } \\
\hline Gajah Mada & 67 & 42 & 62.7 \\
\hline Jendral Sudirman 1 & 47 & 12 & 25.5 \\
\hline Jendral Sudirman 2 & 73 & 87 & 119.2 \\
\hline
\end{tabular}

g) Tingkat Pergantian Parkir 
Survei patroli parkir yang telah dilakukan dapat diketahui volume kendaraan yang menggunakan fasilitas selama waktu survei. Perhitungan ini erat kaitannya dengan kapasitas dan penawaran yang tersedia. Dari kedua komponen tersebut akan diperoleh tingkat pergantian parkir atau turn over.

Tabel 10. Tingkat Pergantian

\begin{tabular}{|c|c|c|c|c|c|c|c|c|c|}
\hline \multirow{2}{*}{ Lokasi Parkir } & \multicolumn{3}{|c|}{$\begin{array}{l}\text { Volume Kendaraan Parkir ( } \\
\text { Kend ) }\end{array}$} & \multicolumn{3}{|c|}{ Kapasitas Statis (Ks) } & \multicolumn{3}{|c|}{$\begin{array}{c}\text { Tingkat Pergantian Parkir } \\
\text { (kend/ruang) }\end{array}$} \\
\hline & Motor & $\begin{array}{c}\text { Mobil } \\
\text { Pribadi }\end{array}$ & $\begin{array}{l}\text { Pick } \\
\text { Up }\end{array}$ & Motor & $\begin{array}{l}\text { Mobil } \\
\text { Pribadi }\end{array}$ & Pick Up & Motor & $\begin{array}{l}\text { Mobil } \\
\text { Pribadi }\end{array}$ & Pick Up \\
\hline Gajah Mada & 359 & 124 & 323 & 67 & 42 & 42 & 5.4 & 3.0 & 7.7 \\
\hline $\begin{array}{c}\text { Jendral } \\
\text { Sudirman I }\end{array}$ & 79 & 124 & 147 & 47 & 37 & 37 & 1.7 & 3.3 & 3.9 \\
\hline $\begin{array}{c}\text { Jendral } \\
\text { Sudirman II }\end{array}$ & 688 & 208 & 64 & 73 & 47 & 47 & 9.4 & 4.4 & 1.4 \\
\hline
\end{tabular}

h) Permintaan Terhadap Penawaran

Hasil analisis yang telah dilakukan dapat diketahui kapasitas parkir yang disediakan (penawaran) dan ruang parkir yang dibutuhkan (permintaan). Permintaan terhadap penawaran bagi kendaraan mobil penumpang dan pick up dapat dilihat dalam Tabel 11 berikut.

Tabel 11. Permintaan Terhadap Penawaran Mobil

\begin{tabular}{|c|c|c|c|c|c|c|}
\hline \multirow{2}{*}{$\begin{array}{l}\text { Lokasi } \\
\text { Parkir }\end{array}$} & \multicolumn{3}{|c|}{ Permintaan (ruang) } & \multirow{2}{*}{$\begin{array}{c}\text { Sudut } \\
\text { Parkir }\left({ }^{0}\right)\end{array}$} & Penawaran & \multirow{2}{*}{$\begin{array}{c}\text { Permintaan } \\
\text { Terhadap } \\
\text { Penawaran }\end{array}$} \\
\hline & $\begin{array}{c}\text { Mobil } \\
\text { Pribadi }\end{array}$ & Pick Up & Total & & $\begin{array}{l}\text { Mobil Pribadi } \\
\text { \& Pick Up }\end{array}$ & \\
\hline \multirow{5}{*}{ Gajah Mada } & \multirow{5}{*}{7} & \multirow{5}{*}{25} & \multirow{5}{*}{32} & 0 & 26 & -6 \\
\hline & & & & 30 & 31 & -1 \\
\hline & & & & 45 & 42 & 10 \\
\hline & & & & 60 & 52 & 20 \\
\hline & & & & 90 & 62 & 30 \\
\hline \multirow{5}{*}{$\begin{array}{c}\text { Jendral } \\
\text { Sudirman I }\end{array}$} & \multirow{5}{*}{9} & \multirow{5}{*}{23} & \multirow{5}{*}{32} & 0 & 23 & -9 \\
\hline & & & & 30 & 28 & -4 \\
\hline & & & & 45 & 37 & 5 \\
\hline & & & & 60 & 46 & 14 \\
\hline & & & & 90 & 55 & 23 \\
\hline \multirow{5}{*}{$\begin{array}{c}\text { Jendral } \\
\text { Sudirman II }\end{array}$} & \multirow{5}{*}{35} & \multirow{5}{*}{16} & \multirow{5}{*}{51} & 0 & 29 & -22 \\
\hline & & & & 30 & 35 & -16 \\
\hline & & & & 45 & 47 & -4 \\
\hline & & & & 60 & 58 & 7 \\
\hline & & & & 90 & 69 & 18 \\
\hline
\end{tabular}


Permintaan terhadap penawaran bagi kendaraan sepeda motor pada tiap-tiap ruas yang dikaji dapat dilihat pada Tabel 12 dibawah ini.

Tabel 12. Permintaan Terhadap Penawaran Sepeda Motor

\begin{tabular}{|c|c|c|c|c|}
\hline \multirow{2}{*}{ Lokasi Parkir } & $\begin{array}{c}\text { Permintaan } \\
\text { (ruang) }\end{array}$ & \multirow{2}{*}{ Sudut Parkir $\left.\mathbf{(}^{\mathbf{0}}\right)$} & Penawaran & \multirow{2}{*}{$\begin{array}{c}\text { Permintaan Terhadap } \\
\text { Penawaran }\end{array}$} \\
\cline { 2 - 3 } & Sepeda Motor & & Speda motor & \\
\hline Gajah Mada & 42 & 90 & 67 & 25 \\
\hline Jendral Sudirman I & 12 & 90 & 47 & 35 \\
\hline Jendral Sudirman II & 87 & 90 & 73 & -14 \\
\hline
\end{tabular}

i) Biaya Pendapatan Parkir

Berdasarkan hasil analisis yang telah dilakukan, dapat diketahui besar biaya pendapatan parkir per hari pada ruas jalan yang dikaji yang dapat dilihat dalam pada Tabel 13.

Tabel 13. Biaya Pendapatan Parkir

\begin{tabular}{|l|l|l|l|l|}
\hline No. & Jenis kendaraan & $\begin{array}{l}\text { Volume } \\
\text { Kendaraan } \\
\text { Parkir }\end{array}$ & Besarnya Tarif (Rp.) & Pendapatan Parkir \\
\hline 1 & Sepeda motor dan sejenisnya & 1126 & $1.000,-/$ sekali parkir & Rp 1.126.000,00 \\
\hline 2 & $\begin{array}{l}\text { Mobil pribadi (Sedan, jeep dan } \\
\text { sejenisnya) }\end{array}$ & 456 & $2.000,-/$ sekali parkir & Rp 912.000,00 \\
\hline 3 & Pick Up dan sejenisnya & 534 & $2.000,-/$ sekali parkir & Rp 1.068.000,00 \\
\hline
\end{tabular}

\section{KESIMPULAN}

Dari hasil analisis penelitian, ditemukan pada ruas Jalan Jendral Sudirman II dengan jumlah kendaraan parkir tertinggi sebanyak 115 kendaraan terjadi pada pukul 17.00-17.15 WIB, Jalan Gajah Mada dengan jumlah kendaraan parkir yaitu 65 kendaraan yang terjadi pada pukul 09.30-09.45 WIB, dan Jalan Jendral Sudirman I dengan jumlah kendaraan parkir tertinggi sebanyak 41 kendaraan yang terjadi pada pukul $12.15-12.30$ WIB. Pola parkir badan jalan pada ruas-ruas tersebut menggunakan sudut $45^{\circ}$ sesuai dengan marka yang disediakan.

Namun terdapat beberapa kendaraan yang masih kurang teratur dalam memarkirkan kendaraannya. Untuk komposisi parkir tertinggi pada Jalan Gajah Mada adalah sepeda motor sebanyak 44,5\%, pada Jendral Sudirman I adalah mobil Pick Up sebanyak $42 \%$ dan pada Jalan Jendral Sudirman II adalah sepeda motor sebanyak $72 \%$. Kinerja ruas terburuk untuk kondisi eksisting terdapat pada ruas Jalan Gajah Mada dengan nilai V/C Rasio 0,55 dan nilai kapasitas jalannya sebesar $2156 \mathrm{smp} / \mathrm{jam}$, nilai kecepatan sebesar 28,23 km/jam, dan untuk nilai kepadatan sebesar $41,72 \mathrm{smp} / \mathrm{km}$.

Untuk menyelesaikan permasalahan tersebut maka diberikan usulan, yaitu optimalisasi sudut parkir yang telah tersedia yakni optimalisasi sudut parkir dengan sudut $0^{0}$ untuk jenis kendaraan mobil atau pick up dan sudut $90^{\circ}$ untuk sepeda motor pada ruas-ruas jalan yang dikaji, maka kinerja ruas jalan di jalan yang dikaji akan meningkat. Setelah dilakukan 
pengoptimalisasi sudut diperoleh hasil kinerja ruas jalan yang terbaik yaitu pada ruas Jalan Jendral Sudirman I dengan V/C rasio sebesar 0,46 dan nilai kapasitas sebesar 2613,12 smp/jam, nilai kecepatan sebesar 38,02 km/jam, dan nilai kepadatan sebesar 31,22 smp/jam.

Maka dengan diterapkannya optimalisasi sudut, kinerja ruas jalan menjadi lebih baik dengan tingkat pelayanan jalan 0,46 atau amat baik dan nilai kepadatan yang menurun sehingga kendaraan yang melintas dapat melaju lebih cepat. Didasarkan dengan KM 14 Tahun 2006 mengenai tingkat pelayanan minimum untuk sebuah ruas jalan adalah $\mathrm{C}$ atau cukup dengan $\mathrm{V} / \mathrm{C}$ ratio $\leq 0,8$ maka dengan menggunakan analisis peramalan jumlah volume kendaraan, didapatkan kesimpulan untuk parkir dengan optimalisasi sudut pada jalan hanya dapat diterapkan hingga akhir tahun 2017.

\section{REFERENSI}

1. Abubakar, Iskandar. 2011. Parkir; Pengantar Perencanaan dan Penyelenggaraan Fasilitas Parkir. Jakarta: Transindo Gastama Media.

2. Direktorat Jenderal Perhubungan Darat. 1996. Mепuju Lalu Lintas dan Angkutan Jalan yang Tertib. Jakarta.

3. Direktorat Jenderal Perhubungan Darat. 1997. Pedoman Manual Kapsitas Jalan Indonesia. Jakarta.

4. Direktorat Jenderal Perhubungan Darat. 1998. Pedoman Perencanaan dan Pengoperasian Fasilitas Parkir. Jakarta.

5. Munawar, Ahmad. 2004. Manajemen Lalu Lintas Perkotaan, Beta Offset. Yogjakarta.

6. Pignataro, L. J. 2005. Traffic Engineering Theory and Practice. New Jersey: Precinte Hall,Inc.,Englewood.

7. Praktek Kerja Lapangan Taruna/i Angkatan XXXV. 2016. Pola Umum Lalu Lintas Dan Angkuta Jalan. Kabupaten Ponorogo.

8. Republik Indonesia, Peraturan Pemerintah Tentang Jaringan Lalu Lintas dan Angkutan Jalan, PP No. 79 Tahun 2013 Departemen Perhubungan, Jakarta. Republik Indonesia , Peraturan Daerah Kabupaten Ponorogo Tentang Retribusi Jasa Umum, PERDA No. 14 Tahun 2011, Dinas Perhubungan Ponorogo.

9. Republik Indonesia, Peraturan Pemerintah Tentang Manajemen dan Rekayasa, Analisis Dampak, serta Manajemen Kebutuhan Lalu Lintas, PP No. 32 Tahun 2011, Departemen Perhubungan, Jakarta.

10. Republik Indonesia, Undang-Undang Tentang Lalu Lintas dan Angkutan Jalan, UU No. 22 Tahun 2009, Departemen Perhubungan, Jakarta.

11. Sugiyono. 2012. Metodelogi Penelitian Kualitatif. Yogyakarta: Rake Sarasin. 